\title{
A Consumer Behavior and Lifestyle with the Interest of Buying As Mediation in Determining Home Purchase with Subsidy Credit in Jember
}

\author{
${ }^{1}$ Adhiimsyah Luthfi, ${ }^{2}$ Andi Sularso, ${ }^{3}$ Imam Suroso \\ ${ }^{1,2,3}$ Faculty of Economics and Business, Jember University Kalimantan Road No. 37, Jember 68132, \\ Indonesia
}

\begin{abstract}
The need for houses is almost never decreasing; this opportunity is exploited by developers to realize government programs related to meeting the needs of subsidized housing mortgages. Developers must be able to know how consumer tastes are changing every day in line with current trends, and it is a challenge for developers to be able to predict future demand. This understanding needs further investigation to find out how consumers consider everything before finally making a decision to buy. The purpose of this study was to analyze and determine the effect of consumer behavior and lifestyle on the interests and decisions of the purchase of subsidized KPR housing in Jember Regency. The sample in this study consumers from 10 developers in Jember were 150 respondents. The results of the analysis show that consumer behavior influences consumer buying interest in the purchase of subsidized housing mortgages, lifestyle influences consumer buying interest in home mortgages, consumer behavior influences consumer purchasing decisions in buying subsidized housing mortgages in Jember, lifestyle has a significant effect on purchasing decisions in buying subsidized housing mortgages in Jember, buying interest influences purchasing decisions in determining the purchase of subsidized housing mortgages in Jember, and based on the results of testing the direct and indirect influence of consumer behavior and lifestyle on purchasing decisions through interest, the results show that the direct influence of consumer behavior and the lifestyle of buying interest and purchasing decisions has a greater influence than indirect influence.
\end{abstract}

Keywords: Consumer Behavior, Lifestyle, Buying Interest and Purchasing Decisions.

\section{Introduction}

Housing development is an effort made to meet one of the basic human needs, as well as to improve the quality of the environment, give direction to the growth of the region, expand employment and drive economic activities in the context of improving and equitable distribution of people's welfare. One aspect of national development is housing development aimed at ensuring that all Indonesians occupy decent homes in a safe, harmonious and orderly environment.

Consumer behavior is important for decision making. Every decision taken by consumers must be based on certain reasons, both directly and indirectly. Process. he consumer decision making process is closely related to psychiatric problems and external factors. Marketers will be easy to describe how the decision process is made by understanding consumer behavior (Amirullah, 2002: 38). Consumer behavior factors such as cultural, social, personal and psychological factors are important and very interesting factors if you can find out more deeply about what is inside and individual thoughts about what can affect them before making a decision to buy goods or services, thus Consumer personality needs to be understood as something related to the selection or purchase of a product because consumers will buy goods that are in accordance with their personality.

Personality is closely related to understanding one's lifestyle, which can be defined as a pattern in which people live and use their money and time. Changes in the dynamic environment cause studies of consumer lifestyles can help marketers understand how consumers think and choose various alternatives. Lifestyle 
perspectives in marketing show the classification of individuals into a group based on what they do, how they spend time, and how they choose to use their income. According to Setiadi (2003: 148), lifestyle is broadly defined as a lifestyle that is identified by how people spend their time (activities) what they consider important in their environment (interests), and what they think about themselves and also the world surrounding. Lifestyle refers to the activity, interest, and opinion (AIO).

In more detail, focus on what people like to do, what is their scope of interest, and what people think about things. A person who has a lifestyle tends to be permanent, then he will understand what his tastes are in choosing the product he wants. Consumer behavior and lifestyle is expe cted to provoke a buying interest, where this is personal and is related to an individual's attitude towards an object, from this theory it can be interpreted as buying interest is the consumer's interest in a particular item or object which ultimately makes a purchase decision (Rahmawati , 2018).

The purchase decision process is the execution of consumers in choosing a product, but to stimulate someone to make a decision the marketer must be able to bring up buying interest first in the minds of consumers. Purchasing interest is one's desire and interest when seeing a product. According to Kotler and Keller (2009: 41), consumer interest is how likely consumers are to buy a brand or how likely they are to move from one brand to another. When buying interest has arisen in someone's mind, then the marketer just lures consumers to make product purchase decisions. Kotler and Armstrong (2008: 129) translate purchasing decisions as a process where consumers recognize the problem, find information about a particular product or brand and evaluate how well each alternative can solve the problem which then leads to a purchasing decision. Consumer purchasing decisions include all the processes consumers go through in identifying problems, finding solutions, evaluating alternatives, and choosing between their buying choices (Mowen and Minor, 2012: 6).

The growth of subsidized KPR housing construction has spread in several cities in Indonesia, one of them is in Jember Regency. The growth of subsidized housing construction in Jember experienced a significant increase due to demand that exceeded the initial target. Jember Regency is one of the centers of economic growth with a fairly high population in Indonesia, where the population is increasing from year to year. This increase in population growth encourages the growth of housing development in Jember Regency, especially the small type with subsidy facilities, which can be seen from the increasing number of developers in Jember, which amounted to 46 developers who are members of the East Java Indonesian Real Estate Association (REI), Jember Commissariat and 42 developers who are members of the Association of Indonesian Housing and Housing Developers (APERSI) Jember.

The urban planning and licensing system that was put in place in Jember Regency provided many opportunities so that many developers took part in building property in this case houses. This development has indeed made it easier for the community to find shelter. The problem of housing and settlements in Jember Regency is actually inseparable from the dynamics that develop in the lives of the people as well as existing government policies. This phenomenon causes the emergence of many developers for subsidized housing in Jember which makes the target market in Jember. The height in Jember comes from various domiciles not only purely from Jember but also as migrants who work in Jember and already have a family. This has increasingly made the level of competition among subsidized KPR homebuyers in Jember increase sharply.

Many studies have been conducted with the theme of consumer behavior, lifestyle, buying interest and purchasing decisions that can be used as a research gap, including research conducted by Mubarok (2015) finding that buying interest has succeeded in being a perfect mediator in the relationship of consumer behavior and lifestyle in influencing Indirect purchasing decisions. Suraputra and Warmika (2017) and Kamaluddin (2018) found that a person's lifestyle has a significant influence in the decision making process to buy a product. However, these results contradict the research of Nora and Nurul (2016) who found that lifestyle has no effect on purchasing decision making. According to Nora and Nurul (2016) in their research that lifestyle does not influence product purchasing decisions. Laela (2015) found that consumer and brand behavior had a positive and significant effect on buying interest, either partially or simultaneously. Wijaya et al., (2018) prove that consumer behavior and lifestyle have a significant effect. However, research conducted by Sujani (2017) suggests the results of research that contradicts that consumer behavior has no 
influence on consumer spending decisions at Indomaret retail. According to Sujani, consumers already have a doctrine or understanding that has been embedded that when deciding to buy some products at Indomaret retail is a necessity and convenience. Currently, consumer behavior and lifestyle that is owned by very determine their decisions when buying interest in the purchase of subsidized housing loans in Jember. This causes marketers or business people in the Jember property sector to be careful in capturing life patterns if they want to increase sales of housing units. The purpose of this study is to examine, analyze and compare between the direct influence of consumer behavior and lifestyle on the decision to purchase subsidized housing in Jember and the indirect influence of consumer behavior and lifestyle through buying interest as a mediation to the decision to purchase a subsidized housing mortgage in Jember.

\section{Literature Review}

\subsection{Effects of Consumer Behavior on Buying Interest}

Consumer behavior is a way to determine consumer patterns for a product that he sees. Consumer behavior is the study of how individuals, groups and organizations choose, buy, use and place goods, services, ideas, or experiences to satisfy their wants and needs (Kotler and Keller, 2016: 166). Chen, et al (2018) state that studying and conducting consumer research can start from the cognitive and affective side to generate buying interest from within consumers. buying interest arises because of the learning process that creates a motivation in consumers to meet their needs and is a psychological aspect that influences the attitudes and behavior of consumers to buy a product that is influenced by the information it receives.

Consumer buying interest is the stage where consumers form their choice among several brands incorporated in the device of choice, then in the end make a purchase of an alternative they like best or the process through which consumers go to buy an item or service based on various considerations (Sukmawati and Suyono in Pramono, 2012). This is in line with the results of research obtained by Laela (2015) which states that increasingly understanding consumer behavior can have an impact or have a good effect on consumer buying interest for the desired product. This means that the better the consumer behavior, the buying interest will increase.

H1: Consumer behavior has a significant effect on buying interest.

\subsection{Effects of Lifestyle on Purchase Interest}

According to Setiadi (2003: 148), lifestyle is broadly defined as a lifestyle that is identified by how people spend their time (activities) what they consider important in their environment (interests), and what they think about themselves and also the world around it (opinions). According to Kotler and Keller (2009: 41), consumer interest is how likely consumers are to buy a brand or how likely they are to move from one brand to another. Schiffman and Kanuk (2008: 201) state that interest is one of the psychological aspects that has a considerable influence on behavioral attitudes.

The results of Nora and Nurul's research (2016) show that everything related to a person's lifestyle cannot influence their perception of the desire to buy a product. Furthermore, the lifestyle of the consumer may lead to an interest in buying a product that is influential and important or even not so important to the product. However, this opinion is not in line with Suraputra and Warmika (2017) and Kamaluddin (2018) found that one's lifestyle is very influential on buying interest in a product. Basically, lifestyle is implemented or can be seen from the attitude and the way a person reacts to the product, so marketers should first study the needs and desires of consumers and communicate more about the company's products through various media so that buying interest from consumers will increase. Kamaluddin and Muhajirin (2018), found that lifestyle has a significant effect on consumers' buying interest in shopping online.

$\mathrm{H} 2$ : Lifestyle has a significant effect on buying interest.

\subsection{Effects of Consumer Behavior on Purchasing Decisions}

Consumer behavior is important for decision making. Every decision taken by a consumer must be based on certain reasons, either directly or indirectly. The consumer decision making process is closely related to psychiatric problems and external factors. By understanding consumer behavior, marketers will be easy to describe how the decision process is made. Decision making is an individual activity that is directly involved in using the goods offered. According to Setiadi (2003: 341), defining a decision involves a choice 
between two or more alternative actions or behaviors. Decisions always require a choice between several different behaviors.

Rafiz et al., (2016), found that cultural, social, personal and psychological factors had a significant influence on purchasing decisions. Puranda and Putu (2017), found that consumer behavior and lifestyle significantly influence the buying process of Wardah cosmetic products. Rahmaningtyas et al., (2017), found that Perceived usefulness, Perceived of use, Perceived trust, Perceived risk, Perceived price had no significant effect on intention to buy and purchasing decisions.

H3: Consumer behavior has a significant effect on purchasing decisions.

\subsection{The Effect of Lifestyle on Purchasing Decisions}

Lifestyle can be a group identity. However, lifestyle will be very relevant to the efforts of marketers to sell their products. In other words, lifestyle changes in a group will have a broad impact on various aspects of consumers related to purchasing decisions (Setiadi 2003: 148). Consumer purchasing decisions include all the processes consumers go through in identifying problems, finding solutions, evaluating alternatives, and choosing between their buying choices (Mowen and Minor, 2012: 6). Meanwhile, according to Kotler and Armstrong (2008: 181) consumer purchasing decisions are buying the most preferred brand from various alternatives, but two factors can be between purchase intention and purchase decision.

Puranda and Putu (2017), found that consumer behavior and lifestyle significantly influence the buying process of Wardah cosmetic products. Wijaya et al., (2018), found that lifestyle and motivation have a significant and partial effect on purchasing decisions. Lubis et al., (2020), found that simultaneously Lifestyle and Social Media had a positive and significant effect on purchasing decisions at B-One Cafe, Medan. While partially: lifestyle variables have a positive and significant effect on purchasing decisions in Bone Kafe, Medan. Social Media Some variables have a positive and significant influence on Purchasing Decisions at B-One Cafe, Medan.

H4: Lifestyle has a significant effect on purchasing decisions.

\subsection{Effect of Purchase Interest on Purchasing Decisions}

Buying interest arises because of the learning process that creates a motivation in consumers to meet their needs and is a psychological aspect that influences the attitudes and behavior of consumers to buy a product that is influenced by the information it receives. Consumer buying interest is the stage where consumers form their choice among several brands incorporated in the device of choice, then in the end make a purchase of an alternative they like best or the process through which consumers go to buy an item or service based on various considerations (Sukmawati and Suyono in Pramono, 2012). Kotler and Armstrong (2008: 129) translate purchasing decisions as a process where consumers recognize the problem, find information about a particular product or brand and evaluate how well each alternative can solve the problem which then leads to a purchasing decision.

Al-Dmour et al., (2017), found that there is a significant influence between variable activities, interests, opinions, demographic on online purchasing. While Rahmaningtyas et al., (2017), found that Perceived usefulness, Perceived of use, Perceived trust, Perceived risk, Perceived price had no significant effect on intention to buy and purchasing decisions.

H5: Buying interest has a significant effect on purchasing decisions.

\section{Methodology}

The design of this study uses explanatory research that aims to explain the causality relationship between two or more symptoms or variables. The population in this study were all housing consumers in Jember Regency. The researcher took a sampling of several objects of the destination and gave questionnaires to several people (respondents) that were available and it was easy for the researcher to be met according to the criteria of the designated purposive sampling. Purposive sampling is to choose a sample so that the sample criteria obtained are truly in accordance with the research to be conducted. Some considerations in determining the sample of this study are in the age range of 25 years-35 years and who have made a subsidized mortgage home purchase for at least 1 year. This research uses SEM (Structural Equation 
Modeling) analysis tool which requires a sample of at least 5 times the number of parameter variables (Hair, 2010: 176). This study has a 150 samples.

\section{Results and Discussion}

\subsection{Result}

\section{a. Overview of Respondents}

Based on the results of data collection conducted, obtained data on consumers who filled out a questionnaire of 150 people, it can be known a general description of age, sex, occupation and area of origin.

Table 1: Characteristics of Respondents

\begin{tabular}{|c|c|c|}
\hline No & Age & Amount \\
\hline 1 & $30-35$ Years & 48 \\
\hline 2 & $36-40$ Years & 100 \\
\hline 3 & $>40$ Years & 2 \\
\hline & Gender & Amount \\
\hline 1 & Male & 406 \\
\hline 2 & Female & Amount \\
\hline & Job & 32 \\
\hline 1 & PNS & 19 \\
\hline 2 & BUMN & 69 \\
\hline 3 & Entrepreneurs & 30 \\
\hline 4 & Private employees & Amount \\
\hline & Region of origin & 143 \\
\hline 1 & Jember & 2 \\
\hline 2 & Bondowoso & 3 \\
\hline 3 & Gresik & \\
\hline 4 & Surabaya & 2 \\
\hline
\end{tabular}

\section{Source: Data processed. 2020}

Based on Table 1, the majority of respondents are based on the age character, aged 36 to 40 years, namely as many as 100 people, which indicates that consumers who buy subsidized housing mortgages in Jember are in the adult age. The majority of consumers who decide to buy subsidized housing loans are male, selfemployed and come from the Jember area.

After testing the validity and reliability of all latent variables that provide valid and reliable results, multivariate data is normal, does not occur multicollinearity and outliers, hen the variable can be followed by a test of the suitability of the model and a test of the significance of the causality of consumer behavior, lifestyle, buying interest and purchasing decisions.

\section{b. Goodness of fit test}

After the assumption test of Structural Equation Modeling (SEM) is fulfilled, a model feasibility test is developed that is developed in the structural equation model, then several feasibility models will be used. Testing the model in SEM aims to see the suitability of the model with the data can be seen in Table 2.

Table 2: SEM Compliance Index

\begin{tabular}{|l|l|l|l|}
\hline Criteria & For cut off value & $\begin{array}{l}\text { Calculation } \\
\text { result }\end{array}$ & Information \\
\hline
\end{tabular}




\begin{tabular}{|l|l|l|l|}
\hline Chi Square & $\left(\leq \mathrm{X}^{2} \mathrm{df}=39\right)$ & $\begin{array}{l}92,088 \\
\text { Prob }=0,281\end{array}$ & Good fit \\
\hline Sign. Prob. & $\geq 0,05$ & 0,281 & Good fit \\
\hline RMSEA & $\leq 0,08$ & 0,024 & Close fit \\
\hline GFI & $\geq 0,90$ & 0,931 & Good fit \\
\hline AGFI & $\geq 0,90$ & 0,902 & Good fit \\
\hline CMIN/DF & $\leq 2$ atau 3 & 1,083 & Good fit \\
\hline TLI & $\geq 0,90$ & 0,924 & Good fit \\
\hline CFI & $\geq 0,90$ & 0,939 & Good fit \\
\hline
\end{tabular}

\section{Source: Data processed 2020.}

Based on Table 2, it is known that from the eight criteria used to assess whether a model is feasible or not, it turns out that seven criteria are met, thus it can be said that the model is acceptable, which means there is a compatibility between the model and the data. The results of testing with the AMOS program provide structural equation modeling results that show the relationships between latent variables such as Figure 1.

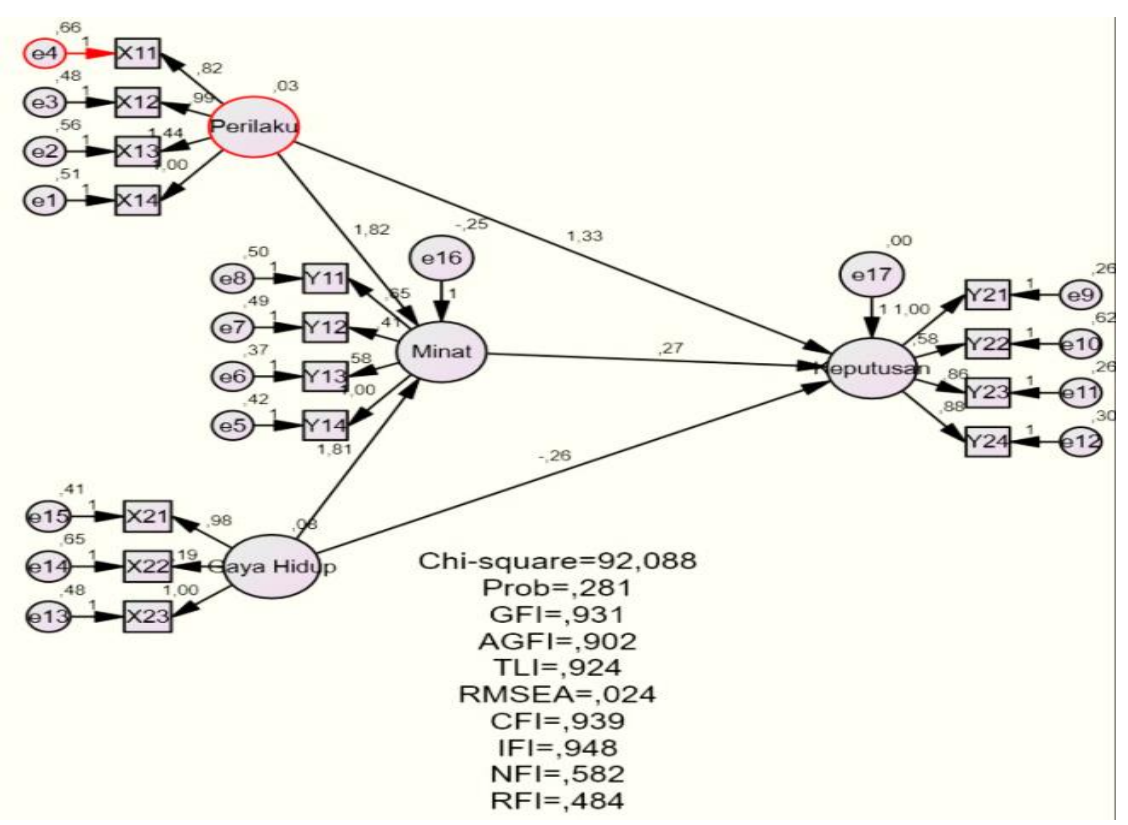

Figure 1: Structural Model

Source: Data processed, 2020

\section{c. Causality Test}

After testing the suitability of the research model, the next step is to test the causality of the hypothesis developed in the research model. Testing the path coefficients in detail is presented in Table 3.

Table 3: Causality Test Results

\begin{tabular}{|l|l|l|l|}
\hline Variable & C.R & Prob. & Information \\
\hline $\mathrm{X}_{1} \rightarrow \mathrm{Y}_{1}$ & 2,497 & 0,035 & Significant \\
\hline $\mathrm{X}_{1} \rightarrow \mathrm{Y}_{2}$ & 2,740 & 0,032 & Significant \\
\hline $\mathrm{X}_{2} \rightarrow \mathrm{Y}_{1}$ & 2,932 & 0,013 & Significant \\
\hline $\mathrm{X}_{2} \rightarrow \mathrm{Y}_{2}$ & 2,781 & 0,025 & Significant \\
\hline $\mathrm{Y}_{1} \rightarrow \mathrm{Y}_{2}$ & 2,198 & 0,031 & Significant \\
\hline
\end{tabular}

Source: Data processed, 2020. 
In structural equations involving many variables and the path between variables there is an influence between one variable with another variable, where the influence includes direct and indirect effects and total influence. Analysis of the influence between variables in this study is used to determine the strength or influence between the variables studied.

\section{d. Direct influence between variables}

In this study the relationship of direct influence occurs between: latent variables exogenous consumer behavior, and lifestyle with latent intervening variables namely buying interest and endogenous variables namely purchasing decisions.

\section{Table 4: Direct Effects of Variables}

\begin{tabular}{|c|c|c|c|c|}
\hline \multirow{2}{*}{ Direct Effect } & \multicolumn{3}{c|}{ Exogenous Variables } \\
\cline { 3 - 5 } \multicolumn{2}{|c|}{} & $\mathrm{X}_{1}$ & $\mathrm{X}_{2}$ & $\mathrm{Y}_{1}$ \\
\hline \multirow{2}{*}{$\begin{array}{c}\text { Endogenous } \\
\text { Variables }\end{array}$} & $\mathrm{Y}_{1}$ & 1,461 & 0,924 & 0,000 \\
\cline { 2 - 5 } & $\mathrm{Y}_{2}$ & 0,239 & 0,765 & 0,302 \\
\hline
\end{tabular}

Source: Data processed, 2020

Direct influence between variables
1. $\mathrm{X} 1 \square \mathrm{Y} 1=1,461$
2. $\mathrm{X} 2 \square \mathrm{Y} 1=0,924$
3. $\mathrm{X} 1 \square \mathrm{Y} 2=0,239$
4. $\mathrm{X} 2 \square \mathrm{Y} 2=0,765$
5. Y1 $\square \mathrm{Y} 2=0,302$

Based on Table 4. and the description above can be seen that the direct influence of consumer behavior, and lifestyle affect buying interest in a positive direction, and buying interest in purchasing decisions in a positive direction. The test results show that consumer behavior has the greatest direct effect on buying interest, meaning that consumer behavior can lead to greater interest which ultimately can create purchasing decisions.

\section{e. Indirect effects between variables}

An indirect relationship occurs between the exogenous latent variables of consumer behavior, and lifestyle of the endogenous latent variable of purchasing decisions through intervening latent variables, namely buying interest. The indirect relationship between variables can be seen from Table 5 .

Table 5: Indirect Variable Effects

\begin{tabular}{|c|c|c|c|}
\hline \multirow{2}{*}{ Indirect influence } & \multicolumn{2}{c|}{ Exogenous Variables } \\
\cline { 3 - 4 } \multicolumn{2}{|c|}{} & $\mathrm{X}_{1}$ & $\mathrm{X}_{2}$ \\
\hline $\begin{array}{c}\text { Endogenous } \\
\text { Variables }\end{array}$ & $\mathrm{Y}_{1}$ &, 000 &, 000 \\
\cline { 2 - 4 } & $\mathrm{Y}_{2}$ &, 441 &, 279 \\
\hline
\end{tabular}

Source: Data processed, 2020.

Indirect influence:

1. $\mathrm{X} 1 \square \mathrm{Y} 1 \square \mathrm{Y} 2=0,441$

2. $\mathrm{X} 2 \square \mathrm{Y} 1 \square \mathrm{Y} 2=0,279$

Based on Table 5. it can be seen that the indirect effect of consumer behavior and lifestyle on consumer purchasing decisions is 0.441 and 0.279 . The greatest indirect effect is consumer behavior on purchasing decisions through buying interest. 
The total effect is an influence caused by the existence of various relationships between variables both direct and indirect influences. Table 6. presents the magnitude of the total influence of consumer behavior, and lifestyle influences buying interest and purchasing decisions.

Table 6: Effect of Total between Variables

\begin{tabular}{|c|l|c|c|c|}
\hline \multirow{2}{*}{ Total effect } & \multicolumn{4}{|c|}{ Exogenous Variables } \\
\cline { 3 - 5 } & \multicolumn{2}{c|}{$\mathbf{X}_{\mathbf{1}}$} & $\mathbf{X}_{\mathbf{2}}$ & $\mathbf{Y}_{\mathbf{1}}$ \\
\hline \multirow{2}{*}{$\begin{array}{c}\text { Endogenous } \\
\text { Variables }\end{array}$} & $\mathrm{Y}_{1}$ & 1,461 & 0,924 & 0,000 \\
\cline { 2 - 5 } & $\mathrm{Y}_{2}$ & 0,202 & 1,045 & 0,302 \\
\hline
\end{tabular}

\section{Source: Data processed, 2020}

Total effect:

$$
\begin{aligned}
& \text { 1. } \mathrm{X} 1 \square \mathrm{Y} 1 \square \mathrm{Y} 2=0,202 \\
& \text { 2. } \mathrm{X} 2 \square \mathrm{Y} 1 \square \mathrm{Y} 2=1,045
\end{aligned}
$$

Based on the results of testing the total effect of the two variables which include consumer behavior, and lifestyle, it can be seen that the total effect is greater than the indirect effect. In total, the biggest influence is the total influence of lifestyle on purchasing decisions. The results of the analysis as a whole indicate that the greatest influence is the direct effect rather than the indirect effect, meaning that the role of buying interest as intervening is small because of the greater direct effect of consumer behavior, and lifestyle on purchasing decisions. Although not big, but buying interest can mediate the influence of consumer behavior, and lifestyle on purchasing decisions.

\subsection{Discussion}

\section{Effect of Consumer Behavior on Buying Interest in Determining Subsidized Mortgage Home Purchases in Jember}

The results of the analysis show that consumer behavior influences consumer buying interest in the purchase of subsidized housing loans, as evidenced by the significant value of $0.035<0.05$. The first hypothesis which states that consumer behavior has a significant effect on buying interest, is accepted. The better consumer behavior, the higher consumer buying interest.

Consumer behavior is how individuals, groups and organizations choose, buy, use and place goods, services, ideas, or experiences to satisfy their wants and needs (Kotler and Keller, 2016: 166). The results showed that the majority of consumers have the following behavior when choosing a residence:

a. has a different character from other culture groups.

b. buy a housing by asking for family opinion in evaluating subsidized housing mortgage that is of interest.

c. buy residential housing subsidized housing that has a good environment in old age.

d. motivated to buy subsidized mortgage housing because they want to secure a future for permanent housing

This behavior can eventually increase buying interest in subsidized KPR houses. Consumers are finally interested in choosing subsidized KPR housing in Jember because with affordable prices but can choose a variety of desired designs, consumers are also willing to recommend a variety of subsidized housing options in Jember, interested in meeting the need for affordable housing and will seek information about subsidized KPR housing in Jember is of interest.

The results of this study are in line with the results of research obtained by Laela (2015) which states that the more understanding of consumer behavior can have an impact or a good effect on consumer buying interest for the desired product. This means that the better the consumer behavior, the buying interest will increase. Consumer buying interest is the stage where consumers form their choice among several brands 
incorporated in the device of choice, then in the end make a purchase of an alternative they like best or the process through which the consumer goes to buy an item or service based on various considerations.

\section{Lifestyle Influence against Buying Interest in Determining Subsidized Mortgage Home Purchases in Jember}

The results of the analysis show that lifestyle influences consumer buying interest in subsidized KPR houses in Jember, with a significance value of 0.013. The second hypothesis which states that lifestyle has a significant effect on buying interest, is accepted. The buying interest is higher, if the lifestyle is also high. Lifestyle is broadly defined as a lifestyle that is identified by how people spend their time, what they think is important in their environment, and what they think about themselves and the world around them (Setiadi, 2003: 148). The lifestyle of a society will be different from other societies. In fact, from time to time the lifestyle of an individual or certain community groups will move dynamically. However, lifestyles do not change rapidly so that at certain periods of time the lifestyle is relatively permanent.

The results showed that the lifestyle of respondents, the majority can be measured by activity, interest and opinion, meaning:

a. consumers buy homes that are located not far from family activities,

b. consumers like dwellings that have a comfortable environment to be with family,

c. consumers are easily influenced by public opinion related to the selection of subsidized KPR housing in Jember.

The higher lifestyle, it will increase consumer buying interest in subsidized housing mortgages in Jember.

Consumers finally have an interest in buying subsidized housing in Jember because with affordable prices but can choose a variety of designs desired, consumers are also willing to recommend a variety of subsidized housing options in Jember, interested in meeting the need for affordable housing and will seek information about subsidized housing KPR in Jember which is of interest.

The results of this study are in line with research conducted by Kamaluddin and Muhajirin (2018), who found that lifestyle has a significant effect on consumers' buying interest in shopping online. Research by Suraputra and Warmika (2017) and Kamaluddin (2018) also found that a person's lifestyle is very influential in buying interest in a product. But this research is not in line with research conducted by Nora and Nurul (2016) who found that everything related to the lifestyle owned by a person cannot influence his perception of the desire to buy a product.

\section{Effect of Consumer Behavior on Purchasing Decisions in Determining Subsidized Mortgage Home Purchases in Jember}

The results of the analysis show that consumer behavior influences consumer purchasing decisions in buying subsidized housing mortgages in Jember, with a significance value of $0.032<0.05$. The third hypothesis which states that consumer behavior has a significant effect on purchasing decisions, is accepted. The better consumer behavior, the higher purchasing decisions.

According to Setiadi (2003: 341), defining a decision involves a choice between two or more alternative actions or behaviors. Decisions always require a choice between several different behaviors. Consumer behavior is important for decision making. Every decision taken by a consumer must be based on certain reasons, either directly or indirectly. The consumer decision making process is closely related to psychiatric problems and external factors.

The results showed that the majority of consumers have the following behavior when choosing housing such as having a different character from other cultural groups, buying housing by asking for family opinion in assessing subsidized housing mortgages of interest, buying subsidized housing housing housing that has a good environment in old age, and motivated to buy subsidized housing because they want to secure a future for permanent housing, so the decision to purchase a subsidized housing type in Jember because it is in accordance with the needs in finding housing, because information from relatives and the media about housing subsidized housing, assessment / evaluation results after the purchase of the selected subsidized 
KPR housing, the decision was right and felt the benefits and advantages of the subsidized KPR housing that I chose.

This study is in line with research conducted by Rafiz et al., (2016), who found that cultural, social, personal and psychological factors have a significant influence on purchasing decisions. Puranda and Putu (2017), found that consumer behavior and lifestyle significantly influence the buying process of Wardah cosmetic products. Rahmaningtyas et al., (2017), found that Perceived usefulness, Perceived of use, Perceived trust, Perceived risk, Perceived price had no significant effect on intention to buy and purchasing decisions.

\section{Lifestyle Influence against Purchasing Decisions in Determining Subsidized Mortgage Home Purchases in Jember}

The results of the analysis show that lifestyle has a significant effect on purchasing decisions in buying subsidized KPR houses in Jember with a significance value of $0.025<0.05$. The fourth hypothesis which states that lifestyle has a significant effect on purchasing decisions, is accepted. The higher the lifestyle that is owned by the consumer, the purchasing decision will also be higher.

Lifestyle can be a group identity. However, lifestyle will be very relevant to the efforts of marketers to sell their products. First, broad trends in lifestyles such as the changing role of buying from men to women, thus changing purchasing habits, tastes and behavior. In other words, lifestyle changes in a group will have a wide impact on various aspects of consumers including purchasing decisions (Setiadi 2003: 148). Kotler and Armstrong (2008: 129) translate purchasing decisions as a process where consumers recognize the problem, find information about a particular product or brand and evaluate how well each alternative can solve the problem which then leads to a purchasing decision. Consumer purchasing decisions include all the processes consumers go through in identifying problems, finding solutions, evaluating alternatives, and choosing between their buying choices (Mowen and Minor, 2012: 6).

The results show that in terms of lifestyle, consumers will buy a residence that is located not far from family activities, consumers like housing that has a comfortable environment to be with the family, and consumers are easily influenced by public opinion related to the selection of subsidized KPR housing in Jember. The lifestyle is ultimately able to improve purchasing decisions, where consumers decide to buy subsidized housing mortgages in Jember because according to the needs in finding shelter, previously consumers will look for complete information from relatives and media about subsidized housing mortgages before making a decision to buy, will do Post-purchase assessment / evaluation of selected subsidized KPR housing brings the right decision and consumers feel satisfied and happy after buying and feel the benefits and advantages of selected subsidized KPR housing.

The results of this study are in line with research conducted by Puranda and Putu (2017), who found that consumer behavior and lifestyle significantly influence the buying decision process of Wardah cosmetic products. Wijaya et al., (2018), found that lifestyle and motivation have a significant and partial effect on purchasing decisions. Lubis et al., (2020), found that simultaneously Lifestyle and Social Media had a positive and significant effect on purchasing decisions at B-One Cafe, Medan.

\section{The Influence of Buying Interest on Purchasing Decisions in Determining Subsidized Mortgage Home Purchases in Jember}

The analysis shows that buying interest has an influence on purchasing decisions in determining the purchase of subsidized KPR houses in Jember with a significance value of $0.031<0.05$. The fifth hypothesis which states that buying interest has a significant effect on purchasing decisions, is accepted. The higher consumer buying interest in subsidized KPR homes in Jember, the purchasing decision will also be higher.

Consumer buying interest is the stage where consumers form their choice among several brands incorporated in the device of choice, then in the end make a purchase of an alternative they like best or the process through which consumers go to buy an item or service based on various considerations (Sukmawati and Suyono in Pramono, 2012). Buying interest arises because of the learning process that creates a motivation in consumers to meet their needs and is a psychological aspect that influences the attitudes and behavior of consumers to buy a product that is influenced by the information it receives. Kotler and Armstrong (2008: 129) translate purchasing decisions as a process where consumers recognize the problem, find information about a particular product or brand and evaluate how well each alternative can solve the 
problem which then leads to a purchasing decision. Consumer purchasing decisions include all the processes consumers go through in identifying problems, finding solutions, evaluating alternatives, and choosing between their buying choices (Mowen and Minor, 2012: 6). Meanwhile, according to Kotler and Armstrong (2008: 181) consumer purchasing decisions are buying the most preferred brand from various alternatives, but two factors can be between purchase intention and purchase decision.

The results also showed that consumers' buying interest in subsidized KPR housing in Jember was due to affordable prices but they could choose various designs they wanted. Consumers were also willing to recommend various housing subsidized housing options in Jember, interested in meeting the need for affordable housing and would seek information about subsidized KPR housing in Jember which is of interest and finally consumers decide to buy subsidized KPR housing in Jember because according to the needs in finding housing, previously consumers will seek complete information from relatives and the media about subsidized KPR housing before making a decision to buy, will do Post-purchase assessment / evaluation of selected subsidized KPR housing brings the right decision and consumers are satisfied and happy after buying and feel the benefits and advantages of the selected subsidized KPR housing.

The results of this study are in line with the research of Al-Dmour et al., (2017), who found that there is a significant influence between the variables activities, interests, opinions, demographic on online purchasing. This study is not in line with research conducted by Rahmaningtyas et al., (2017), found that Perceived usefulness, Perceived of use, Perceived trust, Perceived risk, Perceived price had no significant effect on intention to buy and purchasing decisions.

\section{Direct Effect of Consumer Behavior and Lifestyle on Purchasing Decision of Subsidized Mortgages in Jember and Indirect Effect of Consumer Behavior and Lifestyle Through Purchase Interest as Mediation Against Purchase Decision of Subsidized Mortgages in Jember}

Based on the results of testing the direct and indirect influence of consumer behavior and lifestyle on purchasing decisions through interest, the results show that the results of the direct influence of consumer behavior and lifestyle on buying interest and purchasing decisions have a greater influence than indirect effects, meaning that the role of buying interest as Intervening is small because of the greater direct influence of consumer behavior, and lifestyle on purchasing decisions. Although not big, but buying interest can mediate the influence of consumer behavior, and lifestyle on purchasing decisions

\section{Conclusions}

a. Based on an analysis of the results of the study and discussion, several conclusions can be drawn as follows:

b. Consumer behavior influences consumer buying interest in purchasing subsidized housing loans.

c. lifestyle affects consumer buying interest in home mortgages.

d. Consumer behavior influences consumer purchasing decisions in buying subsidized housing loans in Jember.

e. lifestyle has a significant effect on purchasing decisions in buying subsidized housing loans in Jember.

f. buying interest has an influence on purchasing decisions in determining the purchase of subsidized housing loans in Jember.

g. Based on the results of testing the direct and indirect influence of consumer behavior and lifestyle on purchasing decisions through interest, the results show that the results of the direct influence of consumer behavior and lifestyle on buying interest and purchasing decisions have a greater influence than indirect effects, meaning that the role of buying interest as Intervening is small because of the greater direct influence of consumer behavior, and lifestyle on purchasing decisions. Although not big, but buying interest can mediate the influence of consumer behavior, and lifestyle on purchasing decisions.

Bibliography

[1.] Al-Dmour, Rand., Farah Hammdan, Hani Al-Dmour. 2017. The Effect of Lifestyle on Online Purchasing Decision for Electronic Services : The Jordanian Flying E-Tickets Case. Asian Social Science. Vol.13 No.11 p.157-169.

[2.] Amirullah. 2002. Perilaku Konsumen. Graha Ilmu. Malang. 
[3.] Chen, Chih-Chen, Chien-Wen Chen, Ti-Chun Tung. 2018. Exploring the Consumer Behavior of Intention to Purchase Green Products in Belt and Road Countries : An Empirical Analysis. Journal of Sustainbility MDPI. Vol.10.

[4.] Hair, Joseph E, Jr et al., 2010. Multivariate Data Analysis 7th Edition. Pearson Education Limited. Harlow. England.

[5.] Kamaluddin, Muhajirin. 2018. Pengaruh Gaya Hidup Terhadap Minat Beli Konsumen Dalam Berbelanja Online (Studi Kasus Pada Mahasiswa STIE BIMA). Jurnal AKRAB JUARA. Vol.3, No.3, Hal.113-122.

[6.] Kotler, Philip, Gary Amstrong. 2008. Prinsip-Prinsip Pemasaran. Edisi 12. Penerbit Erlangga. Jakarta.

[7.] Kotler, Philip, Kevin Lane Keller. 2016. Manajemen Pemasaran. Edisi 13 Jilid 1 dan 2. Penerbit Erlangga. Jakarta.

[8.] Laela, Tanti D. Fitra. 2015. Pengaruh Perilaku Konsumen dan Merek Produk Terhadap Minat Beli Produk Fashion Zoya. Jurnal Ilmu Manajemen Ekonologi. Vol.2 No.2.

[9.] Mowen, J.C., M. Minor. 2012. Perilaku Konsumen. Penerbit Erlangga Jakarta.

[10.] Mubarok, Muhammad Mufti. 2015. Pengaruh Brand image dan Sikap Konsumen Terhadap Keputusan Pembelian Batik Jetis Sidoarjo Dimediasi Oleh Minat Beli. Jurnal Bisnis dan Manajemen.

[11.] Nora, Liza., Nurul S. Minarti. 2016. The Role of Religiosity, Lifestyle, Attitude As Determinant.

[12.] Purchase Intention. The 2nd International Multidisciplinary Conference 2. p.135-148.

[13.] Puranda, Nindy Resti., Putu Nina Madiawati. 2017. Pengaruh Perilaku Konsumen dan Gaya Hidup Terhadap Proses Keputusan Pembelian Produk Kosmetik Wardah. Jurnal Bisnis dan Iptek. Vol.10 No.1 Hal.25-36.

[14.] Rafiz, Fadhil Mochammed, Zainul Arifin, Kadarisman Hidayat. 2016. Analisis Pengaruh Perilaku Konsumen Terhadap Keputusan Pembelian MobilMerek Daihatsu (Studi Pada Konsumen Kendaraan Daihatsu di PT. Jolo Abadi Authorized Daihatsu Dealer Malang). Jurnal Administrasi Bisnis (JAB). Vol.39 No.2 hal.105-111.

[15.] Rahmaningtyas, Slamet Hartono, Any Suryantini. 2017. Factors Affecting Online Purchasing of Local Food. Jurnal Agro Ekonomi. Vol.2 No.2 p.189-204.

[16.] Rahmawati. 2018. Pengaruh Harga dan Minat Beli Terhadap Keputusan Pembelian Konsumen Shopee. Jurnal Riset Sains Manajemen (AQLI). Vol.2, No.4, Hal.143-150.

[17.] Schiffman dan Kanuk. 2008. Perilaku Konsumen Edisi 7. Indeks. Jakarta.

[18.] Setiadi, N.J. 2003. Perilaku Konsumen : Konsep dan Implikasi untuk Strategi dan Penelitian Pemasaran. Prenada Media. Jakarta.

[19.] Sujani. 2017. Pengaruh Perilaku Konsumen Terhadap Keputusan Belanja di Indomaret. Majalah Ekryaniuonomi. Vol.XXII No.2 Hal.195-205.

[20.] Suraputra, I Made Widya., I Gede Ketut Warmika. 2017. Pengaruh Gaya Hidup Terhadap Niat Pembelian Sepeda Motor Sport Honda Yang Dimediasi Oleh Sikap. E-Jurnal Manajemen UNUD. Vol.6 No.1 hal.176-203.

[21.] Wijaya, Nata D., Sunarti, Edriana Pangestuti. 2018. Pengaruh Gaya Hidup dan Motivasi Terhadap Keputusan Pembelian (Survei Pada Konsumen Starbucks, Kota Malang). Jurnal Administrasi Bisnis. Vol.55 No.2 Hal.75-8. 